\title{
BM-QFD: an approach to technology entrepreneurship in creating academic spin-offs
}

\author{
Leonel Del Rey de Melo Filho ${ }^{1}$ (D), Raoni Barros Bagno ${ }^{2 *}$ (D), Marina Bastos Carvalhais Barroso ${ }^{3}$, Márcia Dias Diniz Costa ${ }^{4,5}$ \\ ${ }^{1}$ Departamento de Engenharia de Produção, Pontifícia Universidade Católica de Minas Gerais, Belo Horizonte, MG, Brasil \\ ${ }^{2}$ Departamento de Engenharia de Produção, Universidade Federal de Minas Gerais, Belo Horizonte, MG, Brasil \\ ${ }^{3}$ Centro de Pós-Graduação e Pesquisas em Administração, Universidade Federal de Minas Gerais, Belo Horizonte, MG, Brasil \\ ${ }^{4}$ Laboratório de Nanoespectroscopia, Departmento de Física, Universidade Federal de Minas Gerais, Belo Horizonte, MG, Brasil \\ ${ }^{5}$ Instituto Nacional de Metrologia, Qualidade e Tecnologia, Inmetro, Duque de Caxias, RJ, Brasil
}

\begin{abstract}
How to design new products and services in a context of an emergent industry based on cutting-edge science and technology? Current literature on product development and innovation management has long been biased by highlystructured methods oriented to support large-sized established companies operating in known (or knowable) markets, whilst technology entrepreneurship studies are gaining increasing attention in the last years offering more flexible approaches based on a build-measure-learn predominant logic. However, science and technology (S\&T)-intensive products and services intended to explore completely new industries (such as those emerging from the nanomaterials field) seem to be poorly served by available approaches since they might share a few of the assumptions behind them. This study contributes to this field by proposing the BM-QFD as a methodological approach to support the design and development of S\&T-intensive services. Based on the principles of Design Science Research and the genuine demand of a new venture in the science instruments business, a graphene nanometrology service is designed based on TERS - a special technique that applies cutting-edge technology which is essential for the development of nanotechnology. The service design was conducted by adapting well-established methods from the new product/service development literature in combination with those coming from the entrepreneurship field. The resulting proposal is, however, innovative concerning how such methods combine and complement each other in face of the particularities of developing S\&T academic spin-offs.
\end{abstract}

Keywords: technology entrepreneurship, academic spin-offs, technology management, qfd, business model canvas.

\section{Introduction}

Technology entrepreneurship is the recognition, creation, and exploitation of technologies that involve the generation and consolidation of new technology-based companies (Ratinho et al., 2015). In recent years there has been an intense escalation of entrepreneurship activity, definitively putting the term "startup" into the vocabulary of academics and practitioners. In this field, contributions such as the concepts of Lean Startup, Minimum Viable Product, Customer Development (Blank, 2020; Blank \& Dorf, 2012; Ries, 2011, 2017), and others are part of the common vocabulary. These study lines aim to provide methods and management tools to better deal with new technology-based ventures, although the central cases and the dynamic assumptions behind the ideas are normally more adherent to the typical digital-born startup (Bagno et al., 2020; Souza et al., 2018; Souza et al., 2020).

Nascent businesses based on scientific and technological (S\&T) knowledge frontier and intended to explore completely new markets (such as those associated with nanomaterials) face high levels of uncertainty, complexity, and unpredictability (Freitas et al., 2011; Lasmar \& Freitas, 2020; Millar et al., 2018; Shane, 2004, 2005). A systematic approach based on combined processes, methods, and tools (hereafter just called "methods") aims to guide entrepreneurs in reducing uncertainties and risks during the new business generation (Souza et al., 2020). The effectiveness of using managerial tools and methods for uncertainty reduction in innovative and entrepreneurial contexts has long been under debate in the academic and practitioners fields. On one hand, the unpredictability that characterizes innovation projects and new ventures tends to shed light on people's entrepreneurial profiles, creativity, initiative, and other subjective insights (Filion, 1991; Schlesinger \& Kiefer, 2012). On the other hand, when organizational, financial, and customer-driven technical issues emerge, more structured approaches might be of help (Sarasvathy, 2009; Schlesinger \& Kiefer, 2012). In any case, methods for such purposes commonly stem from the context of well-established industrial companies (c.f. Bagno et al., 2017; Salerno et al., 2015) or the more contemporary Digital Entrepreneurship settings (c.f. Souza et al., 2018). As a Received: September 30, 2021. Accepted: November 08, 2021. corresponding author: Raoni Barros Bagno. E-mail: raonibagno@dep.ufmg.br 
consequence, there is a lack of specific methods to support entrepreneurial efforts in science-technologyintensive fields, which typically occur in academic settings and are strongly challenged by high levels of both technical and market uncertainty, long creation and development cycles, and unprecedented potential of disruptions (Ndonzuau et al., 2002; Shane, 2004). Moreover, entrepreneurial and corporate models of innovation, after evolving as separate debates for a long time, are increasingly being faced by the challenges of the current context of dynamic innovation ecosystems which claim for new integrated approaches (Freeman \& Engel, 2007; Gusberti et al., 2010; Morais et al., 2020; Ries, 2017; Souza et al., 2020).

The present study proposes a new approach resulting from combined methods for new product/service development and entrepreneurship to support the creation of science-technology-intensive academic spin-offs, the so-called BM-QFD. This proposal was born from the real demand of a startup focused on developing a specialized service of graphene nanometrology. The next sections present the research context and the details of the methodological strategy (2), a brief review of the selected methods used as the basis of BM-QFD (3), a description of BM-QFD, how it adapts and combines existing methods, how it works, and some debates on the methods' application (4) and, lastly, we present the final remarks and conclusions (5).

\section{Research context and methodological strategy}

The development of this study started from the real need of the startup FabNS (Factory of Nanosoluctions) to develop a business plan to respond to the public call CNPq / MCTIC / SEMPI No 01/2020 for companies and technology-based solutions in the field of graphene. FabNS is a spin-off of LabNS/UFMG (Laboratory of NanoSpectroscopy, Universidade Federal de Minas Gerais), which is primarily formed by researchers from this laboratory who have a strong background in developing and using equipment for nanomaterials characterization. The group has been baking expertise in the TERS (Tip-Enhanced Raman Spectroscopy) technique for about two decades (Costa, 2021; Costa \& Souza, 2019). Such a technique is effective in investigating chemical materials and compounds, including organic and inorganic nanostructures, thin films, and biological materials under environmental conditions in the nanoscale (Costa et al., 2021; Costa, 2021; Rabelo et al., 2019; Rabelo et al., 2020). Recently, LabNS team together with other colleagues had their work on TERS highly recognized by the scientific community after publishing a cover article in Nature Journal (Gadelha et al., 2021).

In this context, our challenge was to design a business plan for a graphene nanometrology service aiming to serve graphene producers. In this project, we designed the service for a potential client here called FGraf. Also, as a formal requirement of the public call, there was a need to develop an MVP Concierge (Ries, 2011) with the potential client.

From the methodological perspective, the study relied on the assumptions and recommendations of Design Science Research (DSR) to develop a management solution within a well-defined problem (Dresch et al., 2019; Van Aken et al., 2016; Van Aken, 2005; Van Aken \& Berends, 2018). DSR is a research strategy to create knowledge that can be used instrumentally to design and implement actions, processes, and systems that achieve expected results in practice. The DSR results from design propositions aimed to support professionals who adopt them as a possible and/or generic solution to a real problem (Van Aken et al., 2016).

A four-step cycle guides the development of a typical DSR: i) review of the existing literature concerning the problem; ii) synthesis of the literature in terms of the given problem; iii) proposition of design principles (alternative solution); and iv) testing of the solution and its principles for further improvement (Van Aken \& Romme, 2009) or even generalization oriented to the construction of formal theory independent of the context (Holmström et al., 2009). Applied to the study in question, the theoretical review summarized in topic 3 represents steps $\mathrm{i}$ and ii, while the presentation of the proposal and discussion of its application in topic 4 concatenate steps iii and iv of this article. The development of the BM-QFD was conducted over five months, distributed in weekly meetings among the authors, eight meetings of about $1.5 \mathrm{~h}$ with representatives of FabNS and FGraf, and three workshops of about $2.5 \mathrm{~h}$ involving representatives of all teams.

\section{The elements of BM-QFD: a brief review of the selected methods}

\subsection{The Quality Function Deployment - QFD}

The QFD method, developed in Japan at the end of the 1960 century, is a way to systematically communicate quality-related information, translating customers' real needs into project information and unfolding the work related to obtaining quality. The focus is on quality assurance during the product development cycle of products (goods and services) (Chan \& Wu, 2002; Cheng, 2002; Cheng \& Melo Filho, 2007, 2010; Freitas et al., 2015; Spinola et al., 2007). Among the main benefits of the QFD, we can mention the following: the improvements in the project, the ability to identify the fundamental perceptions of customers, the flexibility of integration to other methods, the support in data analysis and decision making, and the strengthening of the company's relationship with the market (Borba Prá \& Miguel, 2013; Cheng, 2002). 
In QFD, Quality Deployment is fundamentally a result of the application of cause-and-effect logic in a structured, hierarchical, and prioritized way. The process of deploying the so-called customer's voice (VOC) is made by identifying the quality characteristics of the final product/service and its constituents until reaching a specific value of a product and/or a production process parameter (Cheng \& Melo Filho, 2007). Therefore, further deployments from VOC subsequently go through all the necessary parameters for product/process development and business elements. Such parameters concern product quality characteristics, functions, quality aspects of intermediate products and raw materials, process control parameters, mechanisms, components, standards, among several others, according to the nature of each project (Cheng, 2002, 2003; Cheng \& Melo Filho, 2007).

The tables, organized at levels starting from the more aggregated to the more detailed, represent the mentioned parameters and the VOC (ordered according to their importance). The correlation matrix shows the cause-andeffect relationships between elements of different tables (Figure 1).

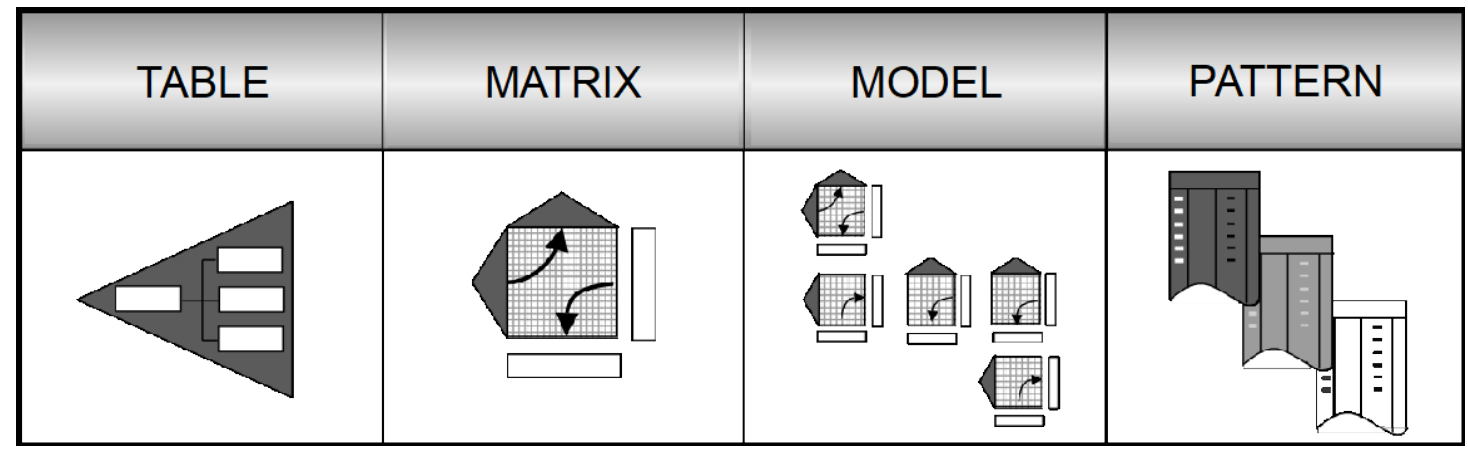

Figure 1. QFD operating units (Cheng \& Melo Filho, 2007).

The set of tables and matrices form the conceptual model of a given product. Whether or not to continue with deployment efforts for specific dimensions (e.g., technology, cost, reliability) depends on the objectives of each initiative. Finally, the functional areas must transmit the resulting product information from the deployment efforts, which is normally made by a set of product-process associated patterns (Cheng, 2002, 2003; Cheng \& Melo Filho, 2007).

\subsection{A reference model for the startup development process}

Since a nascent business goes through several stages until it reaches maturity and demonstrates the ability to operationalize a defined and sustainable business model through organizational structure and repeatable processes (Freeman \& Engel, 2007), it is of paramount importance the adoption of a reference model to guide this process and help entrepreneurs and managers to take action and gain knowledge on the dynamics of creating a new business. Combined methods and tools can support the new business throughout its development stages as it evolves and gets mature.

The literature on innovation management and entrepreneurship offers several perspectives on innovation processes to guide the way from the idea to launch, or to the innovation diffusion in the market (e.g. Bagno et al., 2017; Ndonzuau et al., 2002; Shane, 2004; Silva et al., 2014). Many of these models have implicit biases regarding sectoral or organizational assumptions such as size, market dynamics, the intensity of innovation (e.g., radical or incremental), and the business knowledge base. This is so because, generally, management methods and tools for innovation root in the problems of large manufacturing companies (Bagno et al., 2017; Cheng, 2003; Salerno et al., 2015) or are overly inspired by startups associated with information technologies (e.g., Ries, 2011; Blank \& Dorf, 2012). Although the contributions are rich, this situation requires caution regarding the application of the available models to the context of S\&T-intensive businesses. In this context, the P-Start model (Souza et al., 2018) was selected as the reference to nurture the startup evolving process.

P-Start was first proposed and continuously improved through several real cases in the context of NTQI projects (Núcleo de Tecnologia da Qualidade e Inovação or Technology Center for Quality and Innovation, an applied research group of Universidade Federal de Minas Gerais - UFMG). P-Start focuses on the action by the adoption of quick-learning cycles (typical of contemporary approaches of digital startups) combining them to the discipline and support of structured tools and methods (typical of innovation in established companies) (Sarasvathy, 2009; Schlesinger \& Kiefer, 2012; Souza et al., 2018; Souza et al., 2017). Figure 2 contains a version of the model. 


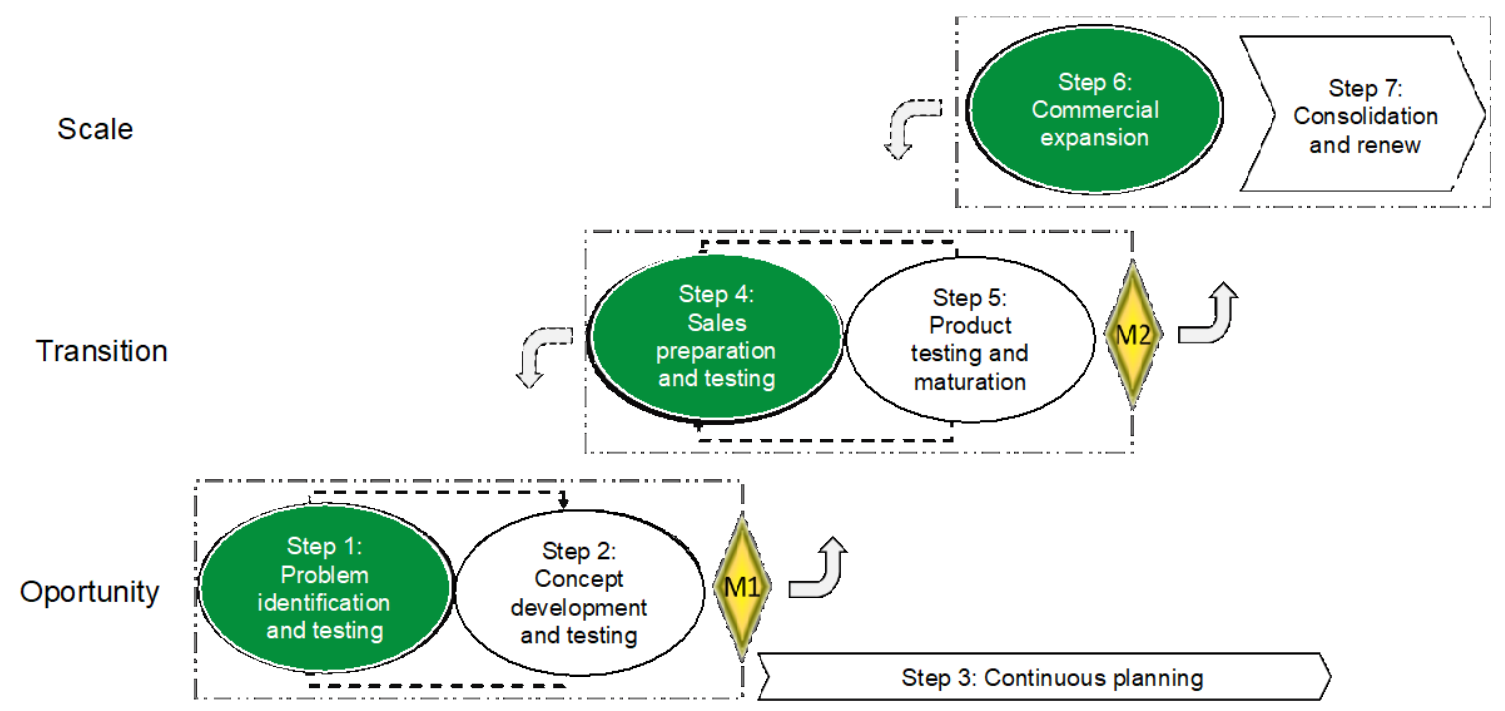

Figure 2. The P-Start model (Souza et al., 2020).

\subsection{Business Model Canvas and Value Proposition Design}

The Business Model Canvas (BMC) is a synthetic representation form of the dimensions that outlines a business and is a visual artifact of the Business Model Generation (BMG) framework (Osterwalder \& Pigneur, 2010). A business model should describe the logic of creating, delivering, and capturing value by the company. The BMC allows visualizing the constituent blocks of the business model on a single page, facilitating the investigation of their hypotheses (Souza et al., 2017).

Osterwalder \& Pigneur (2010) proposed the BMG as an approach for the designing of business models. A business model should describe the logic behind the company's creation, how it delivers and captures value. In this context, the Business Model Canvas (BMC) is the central artifact of BMG, allowing the visualization of the nine constituent blocks of the business model in a single page, facilitating the investigation of its subjacent hypotheses (Souza et al., 2017). Osterwalder et al. (2014) suggested an improvement to the original BMC to which they called Value Proposition Design (VPD) canvas for achieving the product-market fit through the use of other two combined artifacts: the customer profile (which helps to understand what customers do, their potential gains and pains) and the value map (which contains the points to relieve "pains" and create "gains" in terms of what customers do, their potential gains and pains).

\subsection{Service Blueprint}

Shostack (1984) coined the concept of Service Blueprint by addressing the lack of methods for service development and evaluation. The Blueprint is a figure or map that represents precisely the service or a complex system of services so that different agents involved in providing it can understand and deal with the service objectively (Voss, 2003).

In its visual form, Blueprint is a graph that shows the service delivery progress through the process that starts from the contact with the customer and ends with the operation's completion. The matrix represents the steps horizontally, and each component (service-related action) is ordered vertically representing customer proximity levels (Seyring et al., 2009).

Usually, Blueprint is used to develop and visualize the service in all of its aspects, as well as to highlight points for improvement and opportunities as it describes the physical evidence, the different actors involved, their actions, and interdependencies along the journey of service provision (Vianna et al., 2014). This tool allows the visualization of the service development process in its initial stages and considers both the customers' requirements during the service provision process and the company's internal requirements (Seyring et al., 2009). Since services are typically intangible, they usually cannot be experienced through prototypes in their conventional sense (Braga et al., 2020). Therefore, Blueprint allows a good understanding of services as a whole process, while QFD, which acts at a preliminary and more internal level of analysis, helps in the definition of the service parameters. 


\section{The Business Model - Quality Function Deployment (BM-QFD)}

The acronym attributed to our resultant methodology - BM-QFD - derives from the two main elementary methods combined in the model: the BMC and the QFD. Pitayachaval et al. (2017) have also suggested this combination by identifying potential similarities between the BMC's typical applications and the possibilities of QFD in terms of systematic deployment. Moreover, Souza et al. (2017) proposed the joint application of these methods in digital startup development. The BM-QFD combines five methods that support the technology entrepreneurship and innovation framework to nurture the elaboration of two main outputs: the Business Plan and the MVP Concierge (Figure 3).

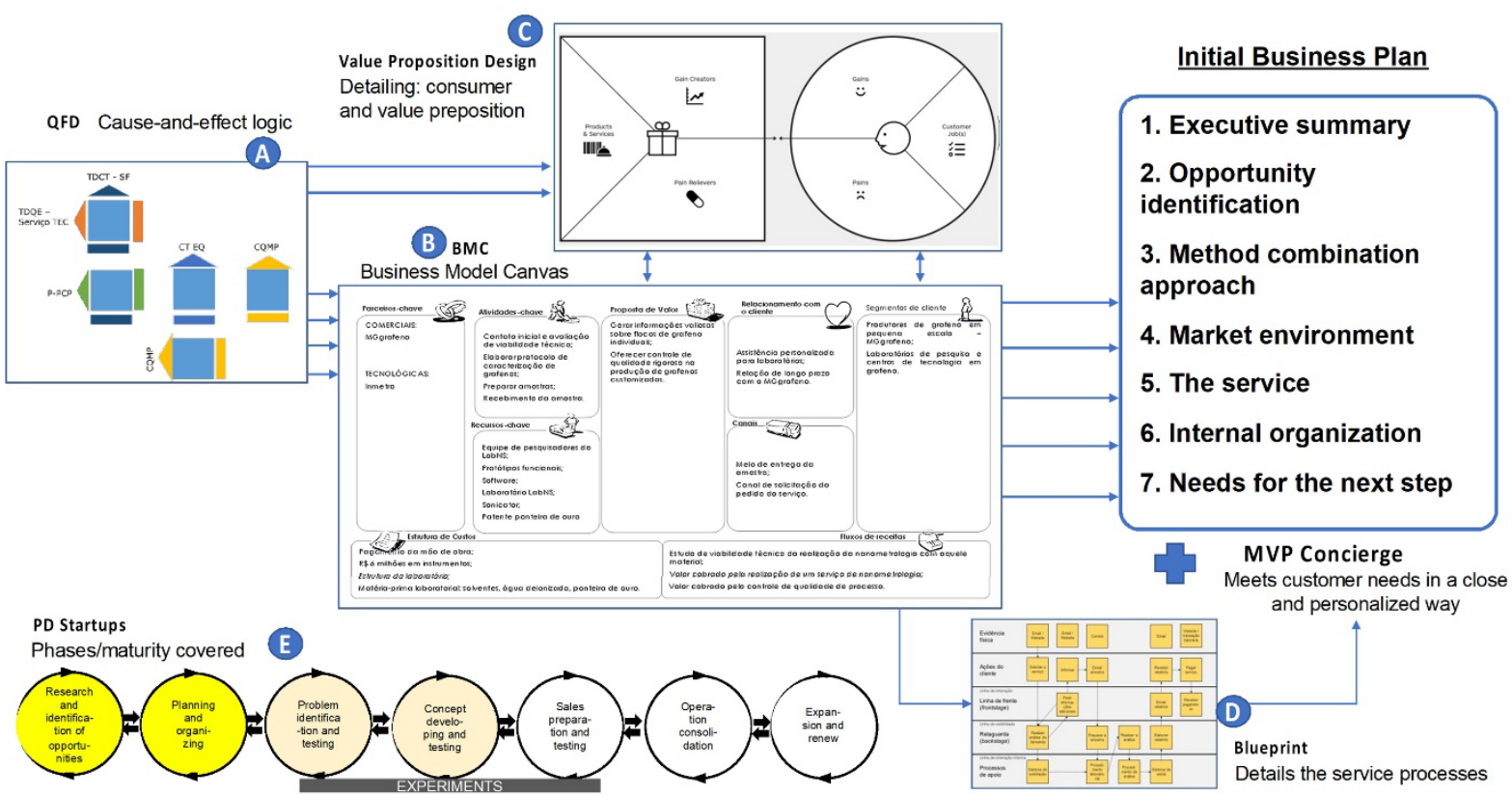

Figure 3. BM-QFD as a combination of methods and tools of innovation and technological entrepreneurship.

The procedural model (Figure 3E) is an adapted version of P-Start and consists of a seven-step framework to support the business and technology development of academic spin-offs. In the present approach, this process is part of the QFD in broad perspective, once it represents the work deployment - the sequence of the work needed to achieve quality standards, in Cheng (2003)'s terms. As shown in the figure, the color intensity of each stage of the process is associated with the business's actual maturity after the efforts made to build the first version of the business plan. Therefore, the first two stages were the best-consolidated ones in terms of uncertainty mitigation at that time. The following two steps were at an intermediate level of completion. Thus, the "future needs" begin to be approached in steps 3 and 4 (described as the "following steps" in item 7 of the business plan), nurturing the next steps of the process (from left to right in Figure 3E).

\subsection{The outputs: Business Plan and MVP}

Two models guide the general structure of the Business Plan. First, we used the basic layers of Technology Roadmapping proposed by Phaal et al. (2010): (1) market and external business environment; (2) product/service portfolio; and (3) internal organization, including resources, technologies, and partnerships. Second, we took Shane (2005) 's model for identifying opportunities for high-tech ventures, which offers a structured set of questions (uncertainties) that the businesses face in their early stages according to some dimensions (e.g. industry maturity, intellectual property issues, resource availability). Thus, seeking answers for such questions serve as a path to leverage business information following a roadmapping framework.

In the case studied, the startup team and the business plan development team worked together to deliver the first version of the plan, which answers questions and uncertainties in coherence with the maturity level evidenced in the stages of the development process. From that point onwards, the business plan works as a living document, periodically reviewed and updated to consolidate previous steps and evidence the progress made. So, we avoid extreme perspectives such as "no plan, just action" or "write all the future today" by using the plan to guide regular discussions on "Where are we now?", "Where do we want to get to?", and "How are we going to 
get there?", using the available information to orchestrate complex interdependencies regarding customers, competitors, operations, and other important business elements according to the development phase (Greene \& Hopp, 2018).

Also, in coherence with the principles of the development process, continuous experimentation was a cross-cutting element between the stages. In the context of this study, it took place mainly through the application of Minimum Viable Products (MVPs). The MVPs not only intended to respond to the service's technical/design questions but also to test the business's fundamental hypotheses as a whole (Blank \& Dorf, 2012; Braga et al., 2020; Ries, 2011). Ries (2011) proposed some types of MVP (smoke, "sell before you build", Wizard of $\mathrm{Oz}$, single feature, concierge). In the specific context of this study, we sought to delineate what is called MVP concierge which meets the needs of a particular client in a close and personalized way (in the case, FGraf). Two distinct levels of MVP Concierge were elaborated:

i) Abstract level Concierge MVP: it was represented by the QFD workshop with FGraf, which focused on elaborating, validating, and prioritizing the identified needs in graphene production. The client's needs were validated in a conceptual plan by prioritizing the planned quality elements and their correlations with the nanometrology service functions and solutions. We can argue that the use of QFD workshops in the role of MVP to validate learning with potential clients is innovative.

ii) Concrete level Concierge MVP: it was represented by the practical realization of nano-characterization of graphenes provided by the client and the practical experience of providing the proposed service.

The abstract and concrete Concierge MVPs can be taken as distinct forms of a genuine service concept. They proved to be useful not just to identify, evaluate and rank the client's needs, but also to adjust the service parameters to increase the client's intent to adopt the service regularly in the future. The results of the abstract concierge MVP can be seen in the first QFD tables and, in the initial design of the business and service represented by the Business Model Canvas, Value Proposition Design, and Blueprint (symbolic elements of the firm and service). Similarly, the concrete concierge MVP was made tangible in the form of a formal technical report that evidenced the firm and service capabilities in practice, with performed measurements and analyses under real samples from FGraf, appreciated and validated by both teams (startup and client).

\subsection{Cause-and-effect relationships as a general guide of the new business and associated service}

In order to serve as a method to support the nascent company's business plan, we used the QFD (Figure $3 \mathrm{~A})$ at a broader level of analysis, associated with the business strategy and its macro parameters - Figures 4 and 5. Thus, starting from an initial correlation matrix between the voice of client (VOC) and the fundamental parameters of the nanometrology service, the QFD conceptual model was then developed by identifying subsequent cause-and-effect relationships in other business dimensions.

During the QFD workshop, FGraf members evaluated, adjusted, and complemented the fields required in the quality table. After, moving to the service requirements table, the client's members were asked to establish the degree of importance of each identified need in light of the expected contribution of the graphene nanometrology service to mitigate or solve such needs. At this time, the FGraf members assigned a numeric value $(1,3$, or 5$)$ to each requirement. Based on these definitions, the authors and the startup team revised the tables.

Following this process, the technical characteristics of the graphene nanometrology service were gradually established based on the client's needs to characterize the first cycle of cause-and-effect relationships for the developing business - customer needs to be met as an effect of the characteristics of the service provided. The requirements table unfolds to the service characteristics table, which was structured according to five fundamental dimensions that presented more significant interaction with the client: (i) the measurement system, focusing on the quality parameters of graphene characterization (e.g., resolution, identification of defects in the nanometric structure and quantification of material layers); (ii) delivery capacity (e.g., service lead-time and flexibility); (iii) Formal report (e.g., form and content); (iv) R\&D capacity (topics associated with the scientific and technological support the startup team can offer, which could subjectively legitimate the provided service and communicate the startup team's competence); and, in addition, (v) Indicators associated with the performance of the company's website to be made in near future. 


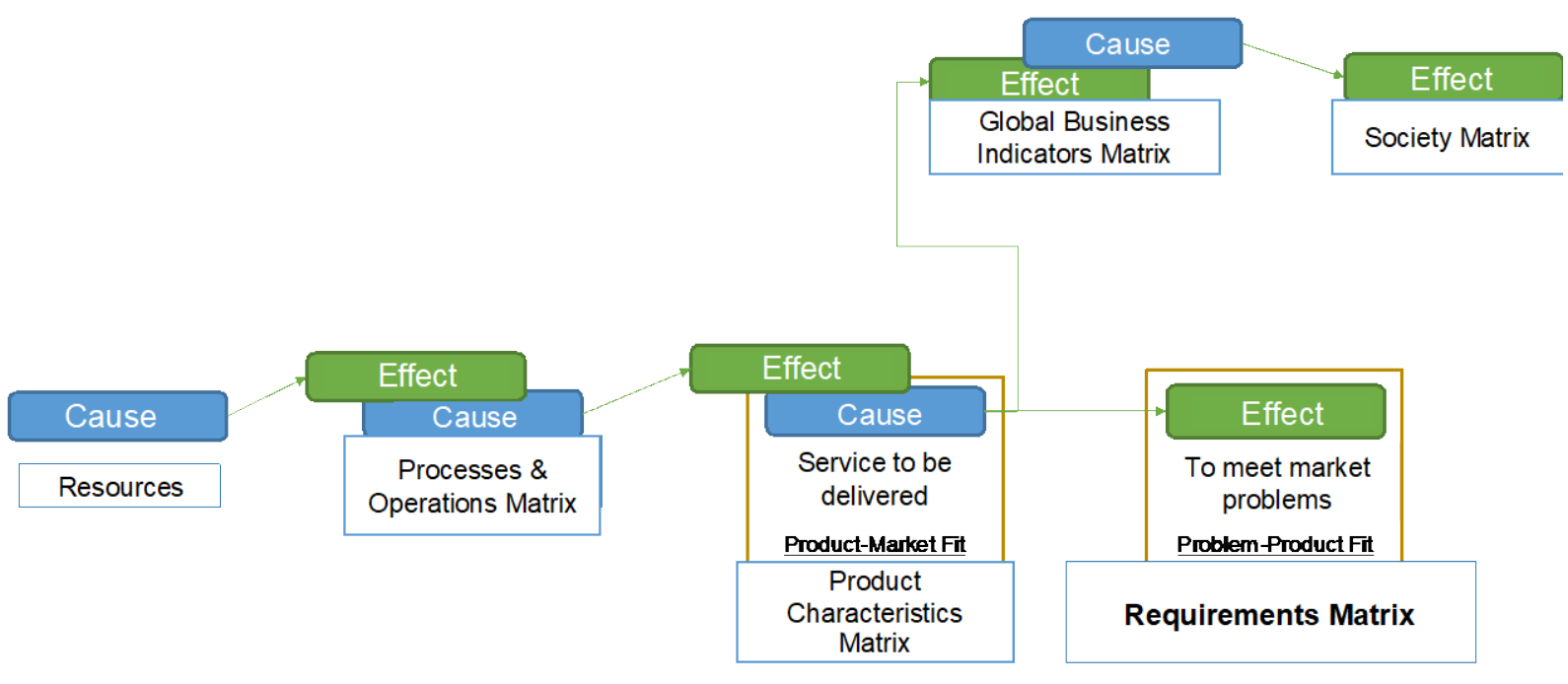

Figure 4. BM-QFD: Cause-and-effect logic unfolded in the dimensions of the business.

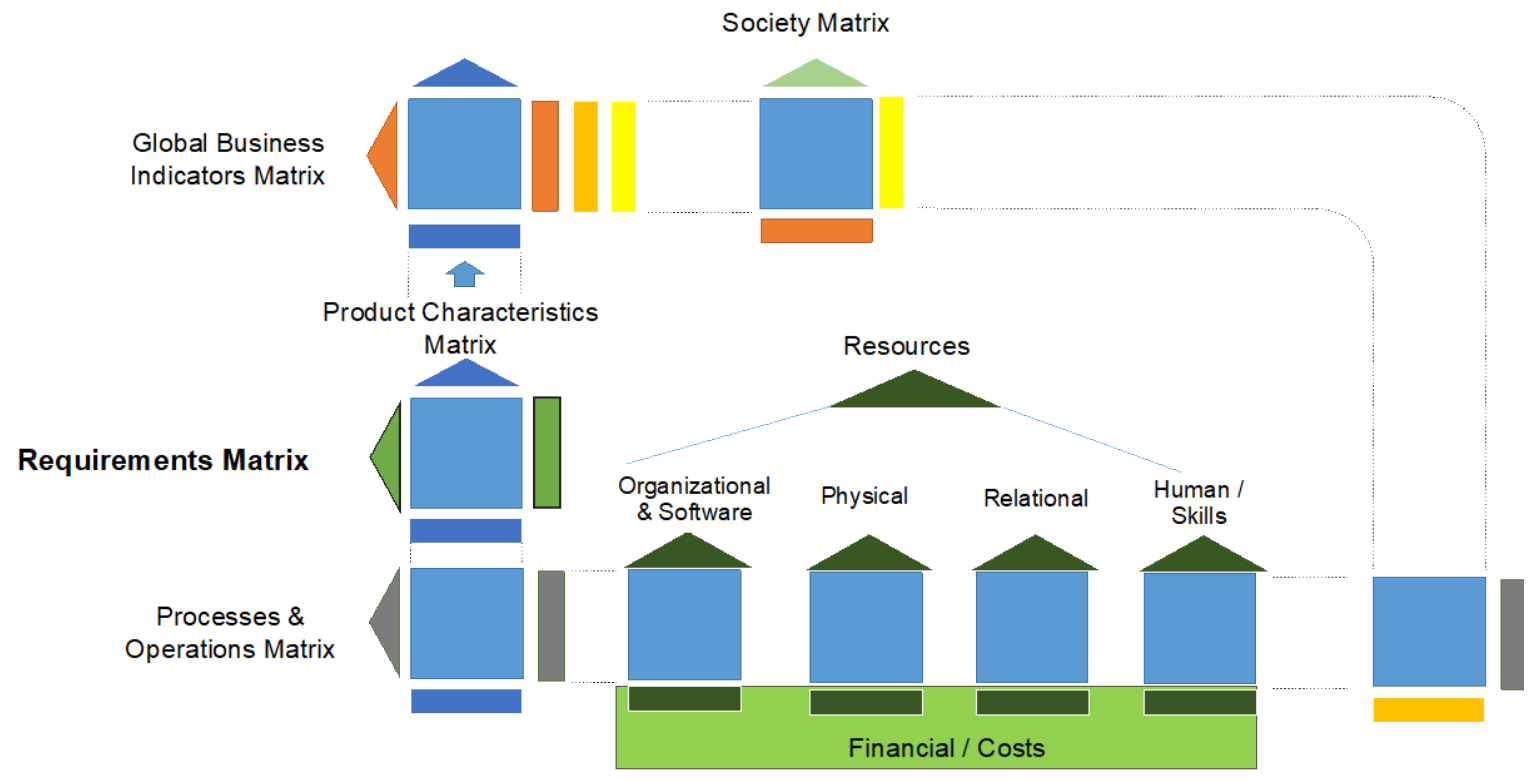

Figure 5. BM-QFD: Conceptual model applied to spin-off development: graphene nanometrology case.

The marks at the intersections of the tables correspond to the correlation perceived intensity (none, 1, 3, or 9) between each service aspect and the client's needs previously identified in the requirements table. The sum of the correlations weighted by the priorities of each requirement leads to the definition of the service characteristics values, which, by turn, establish the level of customer satisfaction obtained by best-performing each quality dimension. The other internal aspects of the business (e.g. Processes \& Operations and Global Business Indicators) can thus be successively deployed in the conceptual model in later stages of the company's development process. Figure 6 shows QFD in action as the abstract MVP in the workshop for testing validated learning with potential clients. 


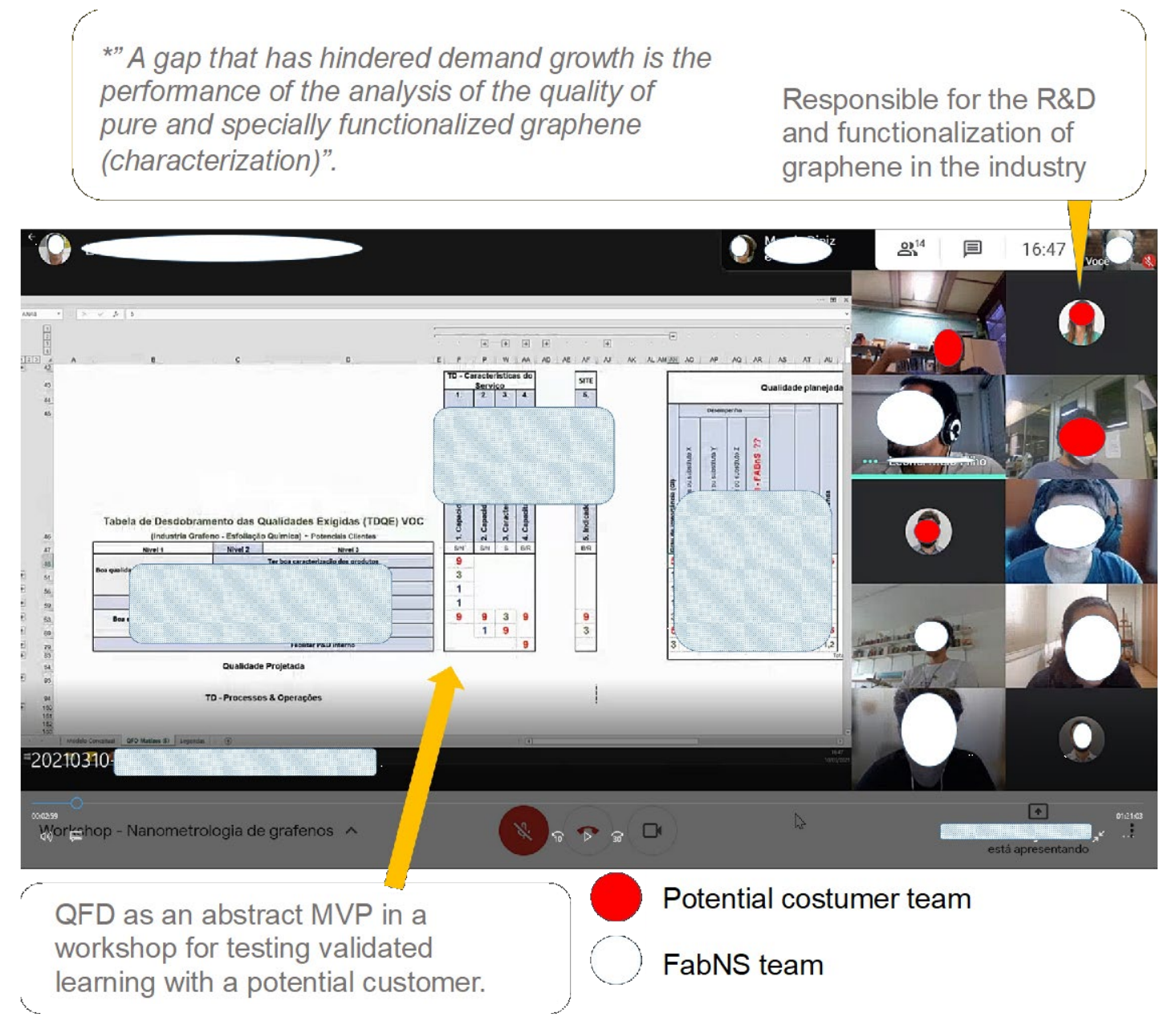

Figure 6. QFD as abstract-MVP in the workshop for testing validated learning with a potential client.

\subsection{Representation artifacts for the business and associated service}

The Business Model Canvas (BMC) and the Value Proposition Design (VPD) are combined (Figure 3BC) to allow a more detailed and significant exploration of the BMC fields of Value Proposition and Market Segments. These fields are the primary triggers for the designing of the business plan. The elements deployed in this effort are essential information for the initial QFD tables (quality requirements and service characteristics). It results in a robust form of $\mathrm{BMC}$, directly supported by the client validation.

Additionally, a Blueprint (Figure 3D) was built to represent the management processes designed through the QFD and actually practiced by the service delivery (the concrete concierge MVP). Since pure services are intangible, they cannot be experienced through prototypes in their conventional sense (Braga et al., 2020). Therefore, the Blueprint provided a better understanding of the services, complementing the QFD tables, which supported a preliminary and more internal analysis during the service definition.

Together, BMC, VPD, and Blueprint were the artifacts that synthesized the business and the specialized service associated with it. These methods communicate the service in a synthetic and visual form, allowing continuous review and reflection on the business, making it more manageable. Also, the QFD at a higher level of abstraction provided a cause-and-effect relationship that was essential to keep concision among all the information fields of the other distinct methods.

\section{Conclusions}

This study aimed to propose the BM-QFD as a methodological approach to support the design and development of S\&T intensive services. Based on the principles of Design Science Research, the study was elaborated upon the genuine demand of Startup FabNS to design a Graphene Nanometrology service based on TERS - a world-class technology that has been proving to be essential for the development of innovations in the field of nanotechnology. 
Our proposal combined and adapted consolidated methods in the literature, usually employed in new product and service development for established companies, and also methods from the typical entrepreneurial activity of nascent businesses. The resulting approach, however, is innovative from the perspective of how these methods are adapted and combined to serve the purposes and specific setting under which the study was developed. The motivation for our proposal of a specific methodological approach lies in the particularities of the current demand, that is:

i) The high uncertainty context of an emerging industry with value chain links yet to be consolidated and roles of the agents in the market environment still to be defined;

ii) The business, that is associated with the provision of a high-tech service intensely based on cutting-edge science, developed under both market and technical uncertainties and absence of regulatory or market standards to take as references;

iii) The need to articulate the demand and design of the service directly in contact with a first potential archetypical customer of the envisioned market.

As opportunities for continuity, it is expected to keep monitoring and interacting with the startup along with the next stages of the business and seek opportunities for new applications and improvements of BM-QFD from the experience of other S\&T-intensive startups of the innovation ecosystem.

\section{Acknowledgements}

The authors thank CNPq - The National Council for Scientific and Technological Development - for the financial support provided to the project that gave rise to this w ork. We also thank the FabNS team and professors Luiz Gustavo de Oliveira Lopes Cançado and Ado Jorio de Vasconcelos for the trust and sense of partnership.

\section{References}

Bagno, R. B., Salerno, M. S., \& Silva, D. O. (2017). Models with graphical representation for innovation management: a literature review. $R \& D$ Management, 47(4), 637-653.

Bagno, R. B., Salerno, M. S., Souza Junior, W. C., \& O’Connor, G. C. (2020). Corporate engagements with startups: antecedents, models, and open questions for innovation management. Product: Management \& Development, 18(1), 39-52.

Blank, S. (2020). The four steps to the epiphany: successful strategies for products that win. Hoboken: John Wiley \& Sons. Blank, S., \& Dorf, B. (2012). The startup owner's manual: the step-by-step guide for building a great company. Pescadero: K\&S Ranch.

Borba Prá, F., \& Miguel, P. A. C. (2013). Evolução na aplicação do QFD: análise de publicações qualificadas em periódicos. Exacta, 11(1), 89-100.

Braga, I. S., Bagno, R. B., \& Souza, M. L. P. (2020). Prototipagem: definições, aplicações e oportunidades no empreendedorismo tecnológico. In R. B. Bagno, M. L. P. d. Souza, \& L. C. Cheng (Eds.), Perspectivas sobre o empreendedorismo tecnológico: da ação empreendedora aos programas de apoio e dinâmica do ecossistema (pp. 225-265). Curitiba: Brazil Publishing.

Chan, L., \& Wu, M. (2002). Quality function deployment: a comprehensive review of its concepts and methods. Quality Engineering, 15(1), 23-35

Cheng, L. C. (2002). A guide for QFD implementation in product development. Product: Management \& Development, 1(3), 5-15.

Cheng, L. C. (2003). QFD in product development: methodological characteristics and a guide for intervention. International Journal of Quality \& Reliability Management, 20(1), 107-122.

Cheng, L. C., \& Melo Filho, L. D. R. (2007). QFD: desdobramento da função qualidade na gestão de desenvolvimento de produtos. Belo Horizonte: Blucher.

Cheng, L. C., \& Melo Filho, L. D. R. (2010). Platform conceptual model in QFD for generic drug. Product: Management \& Development, 8(1), 3-16.

Costa, M. D. D. (2021). Desenvolvimento de instrumentação científica em nanotecnologia: inferências para nanoespectroscopia Raman a partir de Technology Roadmapping retrospectivo adaptado de duas tecnologias consolidadas [Tese de Doutorado]. Universidade Federal de Minas Gerais, Belo Horizonte.

Costa, M. D. D., \& Souza, M. L. P. (2019). Descrição da trajetória de concepção de spin-off acadêmica de alta tecnologia em uma universidade brasileira. In Anais do Seminário comemorativo: os 10 anos do Mestrado Profissional em Inovação Tecnológica e Propriedade Intelectual da UFMG. Belo Horizonte: Even3.

Costa, M. D., Cançado, L. G., \& Jorio, A. (2021). Event chronology analysis of the historical development of tip-enhanced Raman spectroscopy. Journal of Raman Spectroscopy : JRS, 52, 587-599.

Dresch, A., Lacerda, D. P., \& Cauchick-Miguel, P. A. (2019). Design science in operations management: conceptual foundations and literature analysis. Brazilian Journal of Operations \& Production Management, 16(2), 333-346.

Filion, L. J. (1991). Vision and relations: elements for an entrepreneurial metamodel. International Small Business Journal, 9(2), $26-40$.

Freeman, J., \& Engel, J. S. (2007). Models of innovation: startups and mature corporations. California Management Review, 50(1), 94-119. 
Freitas, J. S., Gonçalves, C. A., Cheng, L. C., \& Muniz, R. M. (2011). O fenômeno das spin-offs acadêmicas: estruturando um novo campo de pesquisa no Brasil. RAI Revista de Administração e Inovação, 8(4), 67-87.

Freitas, L. S., Melo Filho, L. D. R., Cheng, L. C., \& Carmo, M. A. Z. (2015). Análise da aplicação do método desdobramento da função qualidade “QFD” em serviços preventivos de polícia. Revista Produção Online, 15(1), 243-275.

Gadelha, A. C., Ohlberg, D. A. A., Rabelo, C., Neto, E. G. S., Vasconcelos, T. L., Campos, J. L., Lemos, J. S., Ornelas, V., Miranda, D., Nadas, R., Santana, F. C., Watanabe, K., Taniguchi, T., Van Troeye, B., Lamparski, M., Meunier, V., Nguyen, V., Paszko, D., Charlier, J., Campos, L. C., Cançado, L. G., Medeiros-Ribeiro, G., \& Jorio, A. (2021). Localization of lattice dynamics in low-angle twisted bilayer graphene. Nature, 590(7846), 405-409. https://doi.org/10.1038/s41586-021-03252-5

Greene, F. J., \& Hopp, C. (2018). When should entrepreneurs write their business plans? Retrieved in 2021, October 30, from https://hbr.org/2018/05/when-should-entrepreneurs-write-their-business-plans

Gusberti, T. D. H., Werner, L., \& Echeveste, M. E. S. (2010). Do established companies and academic spin-off companies need different capabilities for technology development process? A discussion based upon literature models available. Product: Management \& Development, 8(1), 17-32.

Holmström, J., Ketokivi, M., \& Hameri, A. P. (2009). Bridging practice and theory: a design science approach. Decision Sciences, $40(1), 65-87$

Lasmar, T. P., \& Freitas, J. S. (2020). O fenômeno das spin-offs acadêmicas. In R. B. Bagno, M. L. P. d. Souza, \& L. C. Cheng (Eds.), Perspectivas sobre o empreendedorismo tecnológico: da ação empreendedora aos programas de apoio e dinâmica do ecossistema (pp. 581-600). Curitiba: Brazil Publishing.

Millar, C. C., Groth, O., \& Mahon, J. F. (2018). Management innovation in a VUCA world: challenges and recommendations. California Management Review, 61(1), 5-14.

Morais, V. H. F., Vieira, D. M., Bagno, R. B., \& Freitas, J. S. (2020). Past, present, and future of Product Management and Development: a bibliometric study on the contribution and challenges of PMD journal. Product: Management \& Development, $18(2), 111-121$.

Ndonzuau, F. N., Pirnay, F., \& Surlemont, B. (2002). A stage model of academic spin-off creation. Technovation, 22(5), 281-289.

Osterwalder, A., \& Pigneur, Y. (2010). Business model generation: a handbook for visionaries, game changers, and challengers. New York: Wiley.

Osterwalder, A., Pigneur, Y., Bernarda, G., \& Smith, A. (2014). Value proposition design: How to create products and services customers want. New York: Wiley.

Phaal, R., Farrukh, C., \& Probert, D. (2010). Roadmapping for strategy and innovation: aligning technology and markets in a dynamic world. Cambridge: University of Cambridge.

Pitayachaval, P., Chittrakool, K., \& Arjharn, W. (2017). Integration of Business Model Canvas (BMC) and Quality Function Deployment (QFD) to design product. In 4th International Conference on Industrial Engineering and Applications. Japan: IEEE.

Rabelo, C., Miranda, H., Vasconcelos, T. L., Cançado, L. G., \& Jorio, A. (2019). Tip-enhanced Raman spectroscopy of graphene. In 4th International Symposium on Instrumentation Systems, Circuits and Transducers. São Paulo: IEEE Xplore.

Rabelo, C., Vasconcelos, T. L., Publio, B. C., Miranda, H., Cançado, L. G., \& Jorio, A. (2020). Linkage between micro-and nanoraman spectroscopy of defects in graphene. Physical Review Applied, 14(2), 024056

Ratinho, T., Harms, R., \& Walsh, S. (2015). Structuring the Technology Entrepreneurship publication landscape: making sense out of chaos. Technological Forecasting and Social Change, 100, 168-175.

Ries, E. (2011). The lean startup: how today's entrepreneurs use continuous innovation to create radically successful businesses. New York: Currency.

Ries, E. (2017). The startup way: how modern companies use entrepreneurial management to transform culture and drive long-term growth. New York: Currency.

Salerno, M. S., Gomes, L. A. V., Silva, D. O., Bagno, R. B., \& Freitas, S. L. T. U. (2015). Innovation processes: which process for which project? Technovation, 35, 59-70.

Sarasvathy, S. D. (2009). Effectuation: elements of entrepreneurial expertise. Cheltenham: Edward Elgar Publishing.

Schlesinger, L. A., \& Kiefer, C. F. (2012). Just start: take action, embrace uncertainty, create the future. Boston: Harvard Business Review Press.

Seyring, M., Dornberger, U., Suvelza, A., \& Byrnes, T. (2009). Service blueprinting handbook. Germany: University of Leipzig.

Shane, S. A. (2004). Academic entrepreneurship: university spinoffs and wealth creation. Cheltenham: Edward Elgar Publishing.

Shane, S. A. (2005). Finding fertile ground. Upper Saddle River: Wharton School Pub.

Shostack, G. L. (1984). Designing services that deliver. Harvard Business Review, 62(1), 133-139.

Silva, D. O., Bagno, R. B., \& Salerno, M. S. (2014). Modelos para a gestão da inovação: revisão e análise da literatura. Production 24(2), 477-490.

Souza, M. L. P., Melo Filho, L. D. R., Oliveira, C. G. G., Aniceto, M. D., \& Silveira, C. (2017). Aplicação conjunta de métodos no desenvolvimento de startups: descrição e análise crítica. In Anais do Congresso Brasileiro de Inovação e Gestão de Desenvolvimento do Produto. São Paulo: CBGDP.

Souza, M. L. P., Souza, W. C., Freitas, J. S., Melo Filho, L. D. R., \& Bagno, R. B. (2020). Agile roadmapping: a management tool for digital entrepreneurship. IEEE Transactions on Engineering Management, 69(1), 94-108. 
Souza, M. L., Melo Filho, L. D., Bagno, R. B., Souza, W. C., \& Cheng, L. C. (2018). A process model integrated to innovation management tools to support technology entrepreneurship. In D. F. Kocaoglu (Ed.), Portland International Conference on Management of Engineering and Technology. Portland: PICMET.

Spinola, A. T. P., Bezerra, M. B. P., \& Gregolin, J. A. R. (2007). Competitive intelligence: quality function deployment integrated approach to identify innovation opportunities. Product: Management \& Development, 6(1), 11-17.

Van Aken, J. E. (2005). Management research as a design science: articulating the research products of mode 2 knowledge production in management. British Journal of Management, 16(1), 19-36.

Van Aken, J. E., \& Berends, H. (2018). Problem solving in organizations. Cambridge: Cambridge University Press.

Van Aken, J. E., \& Romme, G. (2009). Reinventing the future: adding design science to the repertoire of organization and management studies. Organizational Management Journal, 6(1), 5-12.

Van Aken, J., Chandrasekaran, A., \& Halman, J. (2016). Conducting and publishing design science research: inaugural essay of the design science department of the Journal of Operations Management. Journal of Operations Management, 47, 1-8.

Vianna, M., Vianna, Y., Adler, I. K., Lucena, B. F., \& Russo, B. (2014). Design thinking: inovação em negócios. Rio de Janeiro: MJV press.

Voss, C. A. (2003). Rethinking paradigms of service: service in a virtual environment. International Journal of Operations \& Production Management, 23(1), 88-104. 